Island Studies Journal, Vol. 5, No. 2, 2010, pp. 193-216

\title{
Island Transport, Car Ownership and Use: A Focus on Practices in Cuba, Malta, Mauritius and Singapore
}

James P. Warren

Department of Design, Development, Environment and Materials

The Open University, Milton Keynes, U.K.

j.p.warren@open.ac.uk

Marcus P. Enoch

Department of Civil \& Building Engineering

Loughborough University, Leicestershire, U.K.

m.p.enoch@lboro.ac.uk

\begin{abstract}
Car ownership is growing in many countries and this growth results in further car use and increasing emissions - a trend diametrically opposed to a reduction of transport energy and longer term sustainability targets, and a problem that is particularly acute in island states across the world. The aim of this paper is to consider how various contextual factors influence the development of transport systems in four island states. Within this, the paper seeks to explore how transport systems have developed in Cuba, Mauritius, Malta and Singapore. The paper finds that a number of contextual factors have combined to result in four rather interesting transport outcomes.
\end{abstract}

Keywords: transport, mobility, car ownership, islands, Cuba, Mauritius, Malta, Singapore, vehicle use, emissions, economic development

(C) 2010: Institute of Island Studies, University of Prince Edward Island, Canada.

\section{Introduction}

Private car use - and the economic, social and environmental impact that this activity generates - is rapidly increasing in both developing and developed nations throughout the world (Dargay \& Gately, 1999). In many cases, this is becoming increasingly problematic, and is resulting in significant increases of external outputs such as accidents and emissions (in particular carbon dioxide $-\mathrm{CO}_{2}$ ). Carbon dioxide is for many countries the main marker for climate change and the de facto 'standard' by which many are measuring their efficiency and carbon reductions; yet, reliance on fossil fuel based transport systems remains the main energy vector for many forms of land based transport vehicles.

Island states may be especially susceptible to climate change due to their locations and to their vulnerabilities (Pelling \& Uitto, 2001; Briguglio, 2004; Nurse \& Sem, 2001). Island states also have, in some cases, acute transport related issues (Enoch et al., 2004). Some of these issues include lack of investment in public transport and basic transport infrastructure (such as roads), shortage of new vehicle stocks (with the cleanest technologies), and a geography which is not always suited to high density public centred transport systems despite relatively high levels of urbanization (such as in dispersed archipelagos). In 


\section{J. Warren \& M. Enoch}

addition, it should be noted that issues surrounding air and maritime links are also obviously recognized as being extremely important but are beyond the scope of this paper.

This paper considers how various contextual factors influence the development of transport systems in four island states. Specifically, the paper seeks to explore how transport systems have developed in Cuba, Mauritius, Malta and Singapore.

Section 2 summarizes some of the main trends known about motorization rates, individual car use and emissions, while Section 3 looks more in depth at trends in land transport and policies in island states in order to apply transport issues to the island context. Section 4 then explains the methodology used in the study; Section 5 presents four vignettes to illustrate the various findings; while Section 6 compares these. Section 7 offers conclusions.

\section{Understanding Vehicle Use}

There have been a number of studies looking at factors affecting car use across a range of countries. For example, in a longitudinal review of cars and usage from 1958 to 1980 in 19 developed countries, Tanner (1983) found that among the clearest and strongest influences are those of income levels on the number of cars, and of petrol prices on the sizes of cars and hence how much petrol they use. Button et al. (1993) reviewed vehicle ownership and use in developing countries and confirm that there is a strong relationship between car ownership and the rate of economic growth and that fuel price and income are important influences on fuel in the short term. The study models vehicle ownership and use in low income countries, but specifically leaves out small island states as "special circumstances may influence underlying causal relationships" (p.53). The paper concluded that at the national level the main independent variable influencing ownership is income, while additional variables include the price of fuel, the level of urbanization and the degree of industrialization. Car use depends primarily on the level of vehicle ownership, followed by income, the price of fuel, the degree of urbanization and the extent of the road network. Gakenheimer (1999) reported that car ownership correlated with the top $20 \%$ of income earners in developing countries, and also to the percentage of the population in urban areas. He added that other economic indicators - such as private consumption, industrial production, and the openness of the economy - perform very badly as comparative indicators. Clearly car ownership is a key factor for car use.

To illustrate some of the complex issues connected with car ownership and use, Figure 1 depicts a systems map based on work originally by Potter et al. (2007: 158, Figure c4) which involves a set of economic and social factors that interact with each other at a number of levels.

Figure 1 has 'causes' towards the outside and transport results/effects in the centre (such as congestion). These spill out in terms of the volume of personal travel and externalities such as accidents and $\mathrm{CO}_{2}$ emissions (shown in the bottom right corner). Note that congestion is considered here as both a factor which interacts at the car use supply and demand level and as an outcome (not shown here). 
The sub-systems in the figure include an urban structural system (bottom left) and a socioeconomic sub-system (top, centred). In the centre is the transport sub-system. Finally, external to these sub-systems are a wider range of techno-socio-economic-political 'shaping factors'. In systems methodology one would deem this the boundary, and in the case of land transport systems, the boundary is conveniently the physical and geographical boundary of the island. Travel to the mainland, or to other islands by car-ferry, or by bridge in the case of Singapore, changes the nature of the boundary and the system significantly, as do other external transport links (i.e. air and sea travel), none of which are investigated here. All of these broad shaping factors also interact with each other and it is not the intention of this paper to explain all the interconnections; rather it is to recognize the complexity of the overlying landscape in conjunction with island based transport systems.

Figure 1: Map of factors which contribute to trip demand for a particular country or place resulting in externalities.

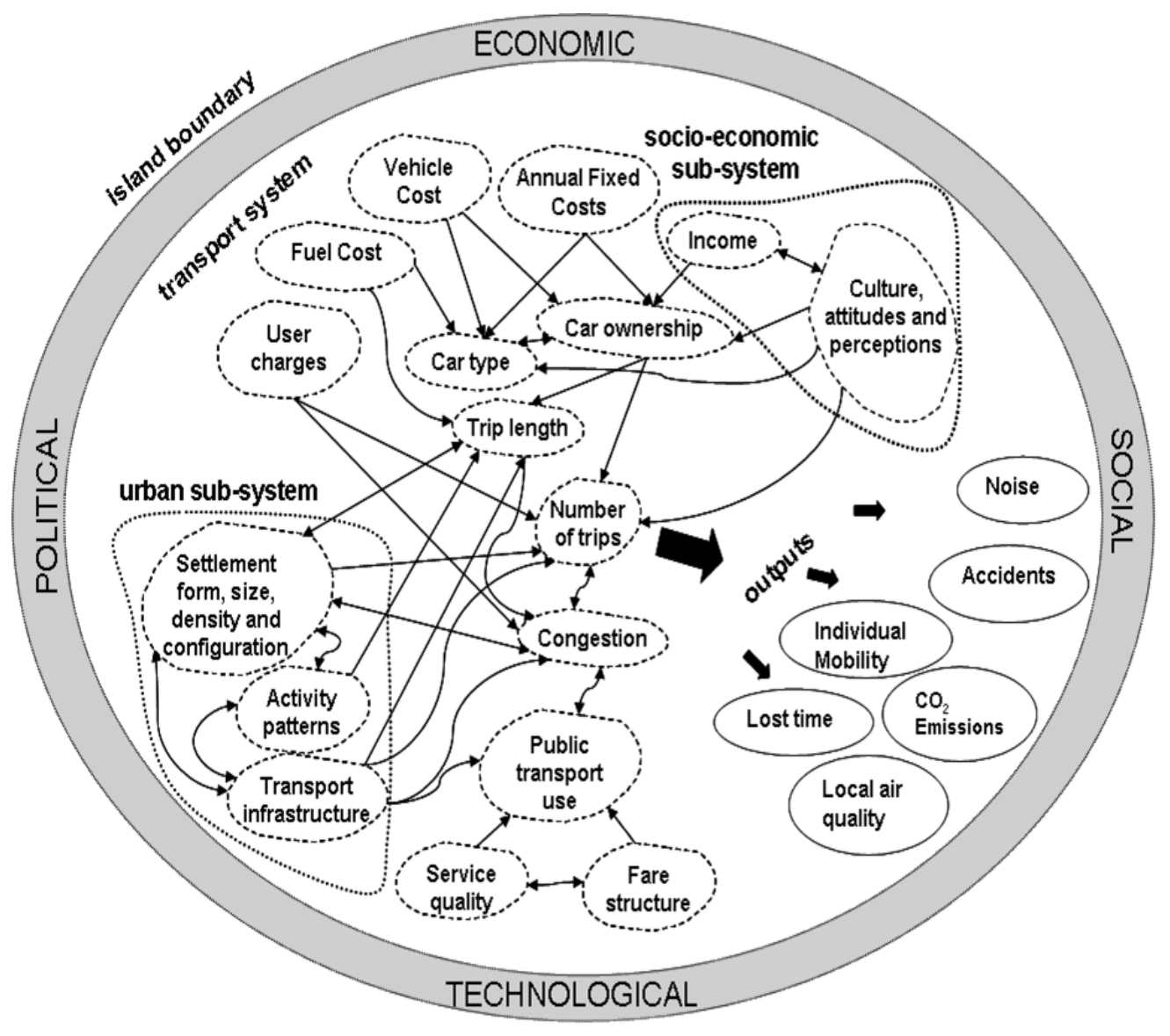




\section{J. Warren \& M. Enoch}

\section{Transport within Island States}

Island states have a combination of economic, social/cultural, geographic, climatic and environmental characteristics that distinguish them from larger and landlocked developing countries (Lockhart et al., 1993; Kakazu, 1994; Weisser, 2004); the interactions of which can generate particular development issues that are often very different from those faced by larger countries. Most obviously, these relate to geographic parameters of smallness and remoteness, as well as the acute outward-looking economic orientation. The combined influences can cause significant economic vulnerability and an inability to pursue economic development without substantial economic support. Finally, the smallness of many island states leads to limited capacities both in terms of production and consumption meaning that they are rarely in a position to develop economies of scale and cannot create substantial internal markets, or in a position to raise large amounts of capital/finance on the home market. Conversely however, it should also be noted that islands can have advantages. For example, Marks et al. (2006: 30) reported that island nations score well for life satisfaction, life expectation and have lower ecological impacts than other countries of comparable wealth perhaps because "the isolation and relative vulnerability have encouraged adaptive and supportive forms of economic and social organisation".

Previous work by the authors of this paper that considered factors affecting car use on 45 SIDS (Enoch \& Warren, 2008), and upon which this paper builds, reports that as with the rest of the world the most significant factor for influencing car use is income, expressed as GDP. Two other primary factors - vehicle-related and population-related variables (vehicles/1000 population and vehicles per unit road length, and population density (inversely) and urban population) - are reported as being significant in at least one of the regression models, whilst neither fuel price nor degree of isolation/remoteness were significant. Interestingly, the same paper reports that car use is two-to-three times lower on SIDS than in the rest of the world for all four income quartiles, and notes that if applied to policy then "more information on the specific contextual conditions evident on each island would really need to be known" (ibid.: 1215). It adds that "the apparent 'disconnectedness' of islands from other territories and influences has led to some seemingly extreme outcomes. Thus, Cuba has experienced severe economic pressures for nearly 50 years while the Government of Singapore has capitalised on its own special circumstances to implement a whole raft of innovative yet potentially controversial transport policy measures since the early 1970s" (ibid.). Finally the paper listed a series of tentative hypotheses relating to the four intrinsic characteristics of island states and car use (ibid.: 1215; 1217):

\section{Smallness}

- Islands generally see facilities located close to one another.

- Political structures are fairly flat vis-a-vis larger countries, therefore making decision making chains rather more direct.

- One would suspect that while the first factor would negate the need or demand for travel to some extent, the second may well increase pressure on decision makers to enhance rather than restrict car use. 


\section{Remoteness}

- Increased levels of remoteness mean high external transport costs limiting the supply of 'transport stocks'.

- It could also mean that the competitive threat from neighbouring jurisdictions is reduced.

- The implication here would be that introducing potentially unpopular policies to restrict traffic growth may be more politically feasible than elsewhere. This may be particularly true if remoteness somehow contributes to islandness.

\section{Demographics}

- Island populations tend to be concentrated in a limited number of centres.

- Island populations tend to be strongly influenced by rapid population changes.

- Together, these trends are likely to exacerbate pressure on land in key locations and thus multiply the externalities caused by the transport system more quickly and more severely than elsewhere.

\section{Economics}

- Diseconomies of scale so relatively expensive to provide transport services and to import vehicles, spare parts, fuel and materials for infrastructure development.

- Islands are particularly vulnerable to fluctuations in energy prices.

- These pressures would seem to lead Island Governments to consider managing car use through restricting travel demand and or improving alternatives rather earlier than elsewhere.

These provide a basis on which the four vignettes to be presented below can be assessed against in order to help give some indication as to the extent that these issues are island related.

\section{Methodology}

The research involved drawing up four case vignettes of four specific SIDS, namely Cuba, Mauritius, Malta and Singapore. These specific island countries were chosen for three reasons:

First, each of the island states are at different stages of a "personal car use-economic development' curve (as represented by Figure 2 which shows how personal car use levels vary as GDP per capita grows).

Thus, Cuba has a low per capita income and low personal car use values and lies at the bottom of the ' $\mathrm{S}$ '-shaped curve (which is shown only as a guide to the eye). Mauritius is observed next along the car use income relationship (with car use now starting to grow rapidly) while Malta is now at a stage where perhaps the growth rate in car use is starting to lessen. Singapore meanwhile could be said to be at the most mature stage in the cycle where GDP is increasing but personal car use is relatively stable. 
Figure 2: Personal motorized car use (km/year/person) as a function of income (GDP) for a range of 39 islands. The case study islands are shown as filled circles and labelled.

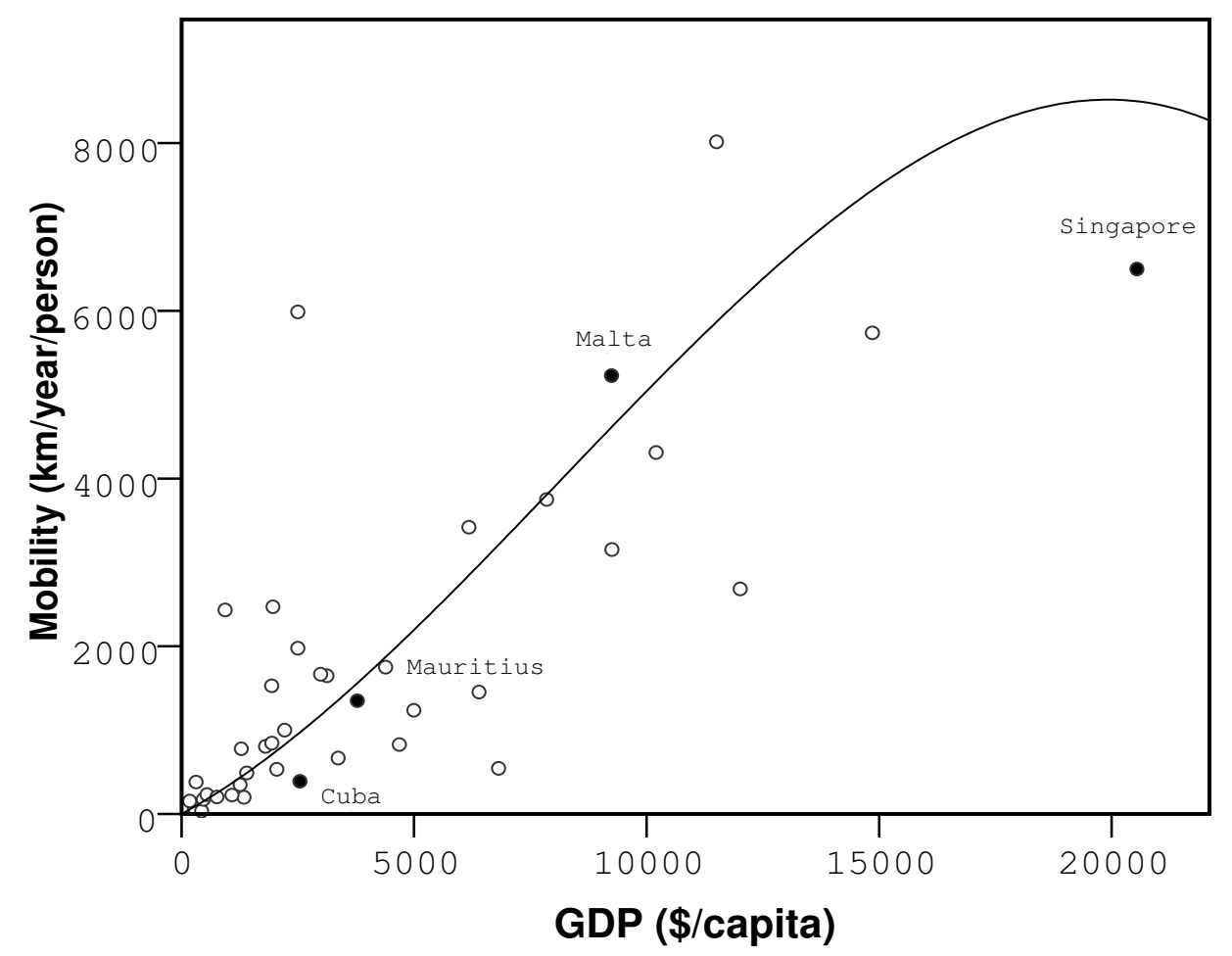

Second, they represent wide spreads in terms of degree of isolation (e.g. Singapore is connected by a causeway to Malaysia and Mauritius is far out in the Indian Ocean), population size, and area (see Table 1 which presents basic descriptions of each island);

Table 1: Location and descriptor factors for the vignettes. Adapted from CIA World Factbook (2006) and Enoch \& Warren (2008).

\begin{tabular}{|l|c|c|c|c|}
\hline \multicolumn{1}{|c|}{ Parameter } & Cuba & Mauritius & Malta & Singapore \\
\hline Population (millions) & 11.29 & 1.21 & 0.39 & 4.16 \\
\hline GDP (\$/cap., PPP) & 2545 (est.) & 3779 & 9245 & 20544 \\
\hline Area $\left(\mathrm{km}^{2}\right)$ & 110,861 & 2,040 & 316 & 685 \\
\hline Population density (person/km²) & 101 & 615 & 1,234 & 6,075 \\
\hline Population growth (\%/year) & 0.31 & 0.82 & 0.42 & 1.42 \\
\hline Degree of isolation & 33 & 87 & 35 & 3 \\
\hline Location & Caribbean & $\begin{array}{c}\text { Indian Ocean, } \\
\text { Africa }\end{array}$ & $\begin{array}{c}\text { Mediterranean, } \\
\text { Europe }\end{array}$ & Southeast Asia \\
\hline
\end{tabular}


Third, unique contextual factors in each case have led to particularly interesting transport policy responses in each case. These are classified in Table 2, such that:

- In Malta, Government is limited in its room for manoeuvre by the tight dual party electoral system whereby the smallness of the country limits the extent to which potentially unpopular policies (e.g. restricting car use) can be applied, resulting in a relatively low level of policy intervention ${ }^{1}$.

- In Cuba too, the policy options available to Government have been heavily restricted (this time because of the prevailing long-term economic and political circumstances); but, in this case, these pressures have forced the authorities to intervene on a number of levels and in a series of innovative ways.

- The case of Singapore is of interest because here the Government effectively chose to adopt a series of controversial car restraint policies unimpeded by restrictions on its ability to meet long term development goals.

- Finally, Mauritius could be said to have a fairly high freedom to act to reduce car use but has so far decided not to pro-actively restrict motorization.

Table 2: Vignettes by degree of policy intervention and level of flexibility of action.

\begin{tabular}{|c|c|c|}
\hline & \multicolumn{2}{|c|}{ Degree of Intervention } \\
\hline $\begin{array}{c}\text { Degree of Governmental } \\
\text { Flexibility of Action }\end{array}$ & Low & High \\
\hline Restricted & Malta & Cuba \\
\hline High & Mauritius & Singapore \\
\hline
\end{tabular}

Data for the vignettes was gathered from a mix of direct observations made on study tours, documentary evidence and from semi-structured interviews undertaken with a number of key stakeholders in each case, all of whom had significant experience of transport policy in their respective countries (see Table 3 for further details). Each interview lasted between one and two hours and consisted largely of open questions based on the following themes:

- Design of the transport system in each case;

- Performance of the transport system in each case;

- Contextual factors that influence the transport system in each case;

- Possible future scenarios in each case.

\footnotetext{
${ }^{1}$ It should be noted here that, despite this, a form of road user charge has been adopted in the capital, Valletta - see later in the paper.
} 
Table 3: Details of Interviewees

\begin{tabular}{|l|l|l|}
\hline & \multicolumn{1}{|c|}{ Interviewee experiences } & \multicolumn{1}{c|}{ Dates conducted } \\
\hline Cuba & $\begin{array}{l}21 \text { (8 Government officials, } \\
5 \text { transport operators, 8 } \\
\text { academics) }\end{array}$ & $\begin{array}{l}\text { April 2002 and July 2004, plus } \\
\text { subsequent communications up to } \\
\text { present day. }\end{array}$ \\
\hline Mauritius & $\begin{array}{l}12 \text { (8 Government officials; } \\
\text { academics) operators; 2 }\end{array}$ & $\begin{array}{l}\text { April 1999, July 2008, April 2009 } \\
\text { and April 2010 plus subsequent } \\
\text { communications up to present day. }\end{array}$ \\
\hline Malta & $\begin{array}{l}8 \text { (5 Government officials, 3 } \\
\text { academics) }\end{array}$ & $\begin{array}{l}\text { April 2008 plus subsequent } \\
\text { communications up to the present } \\
\text { day. }\end{array}$ \\
\hline Singapore & 4 (4 Government officials) & $\begin{array}{l}\text { April 2002 plus subsequent } \\
\text { communications up to July 2008. }\end{array}$ \\
\hline
\end{tabular}

\section{Vignettes}

The purpose of the vignettes is to further explore the various shaping factors encountered in the four SIDS cases of Cuba, Mauritius, Malta and Singapore, and to investigate how transport systems have developed in given island situations as a result of these shaping factors. Note, additional standardised information outlining shaping factors, transport system features and transport outcomes respectively for each of the cases is provided below (see Tables 4, 5 and 6).

\section{Cuba}

Cuba lies $150 \mathrm{~km}$ south of Florida in the Caribbean and is probably unique in having faced severe economic restrictions imposed in 1961 by the United States, its erstwhile principal trading partner, coupled with the collapse of the COMECON countries - its subsequent most important trading partner - during the early 1990s. Consequently, its transport system has developed in several interesting ways (see Enoch et al., 2004; Jatar-Hausman, 1999) which included:

- A strong shift towards walking, cycling and public buses;

- A re-organization of bus routes and bus systems in order to maximize efficiency of route and increase patronage (within the capital Havana);

- A conscious social effort to decrease any trips that were considered unnecessary or unwarranted as well as the proactive provision of collective taxis, organized 'hitchhiking' and an acceptance of higher occupancy in all modes along with fuel rationing;

- A re-emergence of the use of animal traction within both agricultural and local transport arenas especially in the regions outside of the capital; and

- Employers, in some cases, provide transport for their employees in the form of 'enterprise buses' accounting for 10\% of trips in Havana in 1998.

In many ways, Cuba could be considered as an excellent model for sustainable transport practices and overall low emissions, but this has only been achieved with serious 
consequences. Some of these can be summarized as 'supply side' generated issues: there is a severe lack of funding for new road construction and road maintenance, travel demand is not being met by the current supply, there is a shortage of replacement parts, lubricants and new equipment into the market, and non-stability in some supply systems (such as fuels). All of these factors taken together result in a pressure on the car use of individuals and when coupled with certain technological factors and societal factors they lead to outcomes which are extremely difficult for transport users. Many journeys have become nonmotorized with walking and biking becoming prominent modes, even over longer distances.

Regarding public transport, there have been several innovative initiatives for ensuring low flat fare with nearly all urban areas covered in the capital city Havana by either the camello (metro-bus) system or the newer principal route buses. Beyond this many employers are running converted vehicles as buses which collect employees and return them home in the evening each working day. There are also highly equitable collective systems in place using shared taxi rides and standardised fares for popular routes on the main highway where at many junctions a facilitator helps connect people wanting to travel to a similar destination.

The personal car is a minority mode in Cuba, partly due to the vehicle cost barrier for the average Cuban and lack of available funds. Car ownership is low and those who purchase vehicles tend to reduce their running costs by using the vehicle mainly for business purposes, such as taxis and deliveries, rather than for personal use, or by increasing occupancy and sharing fuel costs. In many cases these cars are antiquated and suffer from the shortages despite having handcrafted parts for replacements. In many parts of the country animal traction has also made a resurgence which adds to the complex traffic mix in urban areas.

Demand-side measures also played a major role in Cuba's transport system, particularly in Havana. For instance, many journeys have been completely avoided by relocating certain key workers closer to their work places or vice versa and 'tactical' land use policies designed to reduce trip lengths (such as encouraging mixed use developments) have been introduced. Other 'social' journeys which have been reduced are those which the populace has decided to give up on a voluntary basis.

\section{Mauritius}

The Indian Ocean island of Mauritius has been independent since 1968 and has a growing population of roughly $1.2 \mathrm{~m}$. Largely dependent on the export of sugar cane and tourism for many years, the country's economy has diversified since the early 1990s such that textiles and finance are now almost as important while average individual incomes have risen steadily (Durbarry, 2004). This rapid growth was caused by several factors including a steadily increasing population, increasing incomes in certain groups, migration from rural to urban areas and the greater participation of women in the workforce, and actually led to the existing bus system. In turn, this led to the development of the so-called 'taxi-train' system - a shared taxi scheme providing supplementary bus services particularly in rural areas - as well as to increased car ownership. 


\section{J. Warren \& M. Enoch}

In transport terms, this increasing economic growth is now impacting on the demand for both public and private transport, such that traffic congestion is a major problem at peak times in urban areas. So far the Government has reacted with limited road capacity increases at core locations, a programme of road maintenance improvements, and plans to introduce a rapid transit system (almost certainly now a busway) linking the capital Port Louis with the other large towns in the island (Richmond, 2006). However, while a number of reports have suggested that various demand management measures be introduced in the main urban areas, so far only limited parking restrictions have been applied (Enoch, 2003); and to date there is no definite sign of any major public transport works incorporating a guided bus or light rail/tram development as previously modelled (Halcrow Fox \& MDS Transmodal, 2001).

Perhaps the major barrier to the development of a sustainable transport problem is political, in that political power is often shifted at elections between the two major political parties and their allies. Governments have thus been very reluctant to restrict car use in any way, particularly as it is the aspiration of many of the socially upwardly mobile to own and use a car; meaning that such a policy would likely be extremely unpopular. This reluctance is compounded by the strongly local nature of political activity, whereby politicians are closely linked to the constituencies they represent. Menon (2004) suggested congestion charging based on the Singaporean example, but this has been rejected repeatedly to date.

\section{Malta}

With a population density of more than $1200 / \mathrm{km}^{2}$, Malta is the most densely populated country in the European Union, and is located just south of Sicily in the Mediterranean Sea. As in Mauritius, the export-led economy in recent years has grown rapidly, while tourism also forms an important revenue generator. Politically meanwhile, there are two political parties that are fairly evenly matched. On the personal car use-economic development curve (Figure 2), Malta can be seen to be at a relatively mature stage of its transport development.

From a transport perspective, Malta has some $2,000 \mathrm{~km}$ of road network which is mainly radial, with roads leading towards the capital from most parts of the island. Meanwhile, car ownership levels have increased very quickly with the modal share of private car use having risen from around 55\% of all trips in 1989 to over $70 \%$ in 2002 and the level of car ownership in Malta is now the highest in the European Union. Annual mileage per vehicle has been variously estimated as 3,750 km/yr (in 2000) (EC, 2006) and 5,200 km/yr (Enoch \& Warren, 2008).

Interestingly Malta is well known for its extensive bus network which is currently comprised of some 500 scheduled buses, an extensive network ( $75 \%$ of the population lives within a 5-10 minute walk to a stop) of around 90 routes, relatively high average frequencies and many towns and villages having direct services to the capital. The bus system comprises anywhere from 86,000 to 106,000 trips each day with higher trip numbers during the peak summer seasons. Tourists account for nearly $30 \%$ of all trips although historically bus ticket sales were previously much higher. Indeed, the annual number of bus trips declined by 10 million between 1989 and 2002, and the total current figure is around 30 million trips (Attard, 2005). 
In seeking to explain these circumstances, there are several reasons that should be considered. First, Attard (2005) noted that there is an important social element at play with respect to car ownership. In other words, Maltese culture seems to place a particularly high status on ownership of a car. Second, the close two-party political situation (coupled with the small localized political constituencies) within the island means politicians are generally reluctant to curb car use for fear of upsetting motorists and thus damaging their chances of being (re)elected. Similar constraints also limited progress in modernizing the public bus system for a number of years. Third, Malta also has some difficult issues which relate directly to the EU-accession requirements (Attard \& Hall, 2003). These include the need for cleaner transport fuels, control of emissions during the storage and dispensing of fuels and the introduction of environmental impact assessments for transport projects (such as new roads and infrastructure). Fourth, it could also be argued that tourism in Malta has led to further increased demand for transport and thus exacerbated a number of adverse effects including extra traffic, pressure on public transport, and increased congestion (Bramwell, 2006).

Overall, while land use planning has been tightly controlled over the past two decades, transport planning policies have generally been much weaker, meaning that car use has been relatively unconstrained. However, it should also be noted that there is one main exception to this, which has occurred in the capital Valletta. Here, an annual license fee (of $€ 46 / y r$ in 2002) was imposed on drivers who wished to enter the historic centre until 2007, when it was replaced by a form of road user charging (Attard \& Ison, 2010).

\section{Singapore}

Singapore is a relatively well-developed small island nation located just off to the southern tip of Malaysia at the crossroads of the Indian and Pacific Oceans and is the most 'developed' if one uses economic indicators as the main way of characterizing the four case vignettes. In transport terms, Singapore has a long held and well-deserved reputation as being at the cutting edge in the field of managing the demand for car use. Several policies are worthy of note (Willoughby, 2001).

First, Singapore has operated a range of road user charging schemes since 1975 in order to mitigate rising congestion levels generated by very nearly full employment coupled with a rapidly growing economy as a manufacturing and financial hub. Initially, this was a manually enforced area-wide road user charging scheme which consisted of a complete cordon around a Restricted Zone (RZ) - effectively the Central Business District area where motorists entering through one of 33 entry points had to buy coupons at booths by the side of the road or at petrol stations. However, in 1998, the system was automated and in 1999 it was replaced with an electronic road pricing system to reduce labour costs and to allow for pricing to be used to reduce congestion. Here, drivers must charge up a smart card to insert into a meter on the dashboard which is then debited every time the vehicle passes under a gantry. In addition, petrol taxes make up $35 \%$ of the pump price.

The second approach has been to limit car ownership. This has drawn on several mechanisms including an import fee worth $130 \%$ of the open market value of the vehicle, an excise tax of $20 \%$, and a registration fee of US $\$ 90$, although there is no purchase tax. However, despite these measures, in 1990 the Government introduced yet another measure 


\section{J. Warren \& M. Enoch}

to cut the growth of the car population from $6 \%$ a year to $3 \%$ a year. Thus, under the Vehicle Quota System (VQS), prospective car owners must bid for a Certificate of Entitlement (current average cost of a COE is approximately US\$20,000).

Thirdly, both the supply of proposed parking spaces and the price of existing parking spaces have been tightly controlled for many years, although some measures such as the Parking Place Surcharge - a levy on workplace parking spaces - have been relaxed over the years since the introduction of the ERP scheme, thus further restricting car use (KianKeong et al., 2004).

Finally, the Singaporean Government exerts strong control over land use policy through a long range development plan for the country (with a 40-50 year horizon); while it also owns most of the land on the island. Such a strong land use planning basis has allowed a number of core corridors to be developed to a density high enough to support the Singapore Mass Rapid Transit (SMRT) network, a high quality public transport system focused on a single Central Business District which provides a genuine alternative to those who have been 'persuaded' not to drive; and the development of which continues apace (Richmond, 2008).

Reasons for this rare development path have been attributed to various factors, including:

- The stable political environment whereby the people have apparently been content to accept reduced democratic input so long as living standards have continued to rise - a position that has largely been maintained since independence in 1965 .

- Singapore has tended to see itself in competition with other centres on a global basis, rather than a local or regional one due to its relative isolation from directly competing centres in Malaysia and to a lesser extent, Indonesia.

\section{Comparative analysis}

The following tables summarize a much broader range of information for each of the case studies. These are not meant to be exhaustive but instead illustrate the shaping factors which contribute to the overall transportation situation within each case.

For example, Table 4 lists the outcomes from each country's transport system. Personal vehicle use is lowest in Cuba and Mauritius and, whilst personal car use is higher in Malta than Singapore, overall better public transport access in Singapore means average total motorised mobility is higher in the latter. Looking at the contribution of transport to overall energy use, for Cuba (at 11\%) the suppression of transport demand here is highlighted. In contrast, the figure for Malta (at 60\%) probably reflects that country's high car ownership levels coupled with the lack of a significant industrial base. Corresponding figures for Mauritius and Singapore are both around $45 \%$ : fairly high when compared to larger states.

Next, Table 5 outlines the political dimensions whereby both Cuba and Singapore are governed by single party systems, whilst Mauritius and Malta function under multi-party systems. Interestingly, other variables follow this divide so that land use is more tightly controlled in Cuba and Singapore whilst bus (and rail) services are publicly owned and operated. By contrast, land use controls are not as strong and public transport is privately 
owned in Mauritius and Malta. From an economic angle, all four countries recently have shown positive growth, largely based on exports, particularly in Mauritius, Malta and Singapore. Linked to this, social indicators show all four nations scoring highly for 'human development' and 'happiness'. Technologically, each vignette highlights a fairly high degree of innovation in the transport sector.

Finally the core points to note from Table 6, which documents some of the important transport related descriptions within each vignette, are as follows:

- Each is heavily urbanized and capital-city centered.

- Regarding activity patterns, Cuba has a severely constrained transport supply (that is in poor condition) and consequently demand is suppressed, whereas in the other three cases demand is largely accommodated.

- Fuel and vehicle use costs are relatively high in all four cases.

- Levels of vehicle ownership increase from 45/1000 people in Cuba to 111 in Mauritius to 175 in Singapore and 675 in Malta (despite average Maltese incomes being less than half those of Singaporeans).

Table 4: Output Indicators

\begin{tabular}{|c|c|c|c|c|}
\hline Output indicator & Cuba & Mauritius & Malta & Singapore \\
\hline $\begin{array}{l}\text { Personal motorised } \\
\text { mobility (km/year) }\end{array}$ & $\sim 400$ & 1,350 & 5,230 & 6,498 \\
\hline Personal car use (km/year) & $\mathrm{N} / \mathrm{A}$ & $\mathrm{N} / \mathrm{A}$ & 3,735 & 2,041 \\
\hline $\begin{array}{l}\text { Deaths due to traffic } \\
\text { accidents (no./year) } \\
\text { [no./population] }\end{array}$ & $\begin{array}{c}1,309 \\
{[0.116]}\end{array}$ & $\begin{array}{c}163 \\
{[0.135]}\end{array}$ & $\begin{array}{c}13 \\
{[0.033]}\end{array}$ & $\begin{array}{c}\sim 400 \\
{[0.096]}\end{array}$ \\
\hline $\begin{array}{c}\text { Transport energy (\% of } \\
\text { total) }\end{array}$ & 11 & 45 (est.) & 60 & 43 \\
\hline $\begin{array}{c}\text { Emissions }\left(\mathrm{CO}_{2} \text { total, }\right. \\
\text { tonnes/cap.) }\end{array}$ & 2.23 & 1.41 & 4.48 & 8.56 \\
\hline $\begin{array}{c}\text { Eco-footprint (global } \\
\text { ha/cap.) }\end{array}$ & 1.54 & 1.9 & 6.4 & $\sim 4$ (estimate) \\
\hline Congestion levels & $\begin{array}{l}\text { Low/very } \\
\text { limited }\end{array}$ & $\begin{array}{l}\text { Congestion during } \\
\text { peak hours } \\
\text { (especially in capital } \\
\text { and main urban } \\
\text { areas). Rising over } \\
\text { time. }\end{array}$ & $\begin{array}{l}\text { Very high, } \\
\text { especially during } \\
\text { peak tourism } \\
\text { season; charging } \\
\text { has begun formally } \\
\text { in Valletta }\end{array}$ & $\begin{array}{l}\text { Limited } \\
\text { congestion, car } \\
\text { ownership seems } \\
\text { to have stabilised } \\
\text { (lower than most } \\
\text { EU countries). }\end{array}$ \\
\hline
\end{tabular}

Notes: Personal car use from IRF (2005). Eco-footprint for Singapore estimated from AsiaPacific average of 1.3 (ranging from 0.5 for Bangladesh to 7.7 for Australia), based on GFN, 2006 (Global Footprint Network); in Marks et al., this is reported as 6. Accident rate and deaths in Malta from NSO Malta (2006), for year 2003. 
Table 5: Shaping factor descriptions of political, economic, social and technological indicators.

\begin{tabular}{|c|c|c|c|c|}
\hline Dimension & Cuba & Mauritius & Malta & Singapore \\
\hline $\begin{array}{l}\text { Political parties and Index of } \\
\text { Democracy (Kekic, 2006) } \\
\text { (scale of } 1 \text { to } 10 \text { with higher } \\
\text { being likened to a full } \\
\text { democracy) }\end{array}$ & $\begin{array}{l}\text { Single party state. } 3.52 \text {, authoritarian } \\
\text { regime, ranked } 124 \text { (of } 167 \text { ) }\end{array}$ & $\begin{array}{l}\text { Multiparty system. Political } \\
\text { control can switch between } \\
\text { two coalition groups. } 8.04 \text {, } \\
\text { full democracy, ranked } 25 \\
\text { (of 167) }\end{array}$ & $\begin{array}{l}\text { Dual party system where } \\
\text { political control regularly } \\
\text { switches between the two. } \\
8.39 \text {, full democracy, ranked } \\
15 \text { (of } 167 \text { ) }\end{array}$ & $\begin{array}{l}\text { Multiparty, although in practice } \\
\text { same party in power since } \\
\text { independence in } 1965 \text {. } 5.89 \text {, } \\
\text { hybrid regime, ranked } 84 \text { (of } 167 \text { ) }\end{array}$ \\
\hline $\begin{array}{l}\text { Organisation of interests and } \\
\text { power distribution }\end{array}$ & $\begin{array}{l}\text { Strongly centralised Communist } \\
\text { Party state. Top down policy } \\
\text { diffusion with limited public } \\
\text { participation. }\end{array}$ & $\begin{array}{l}\text { Centralised, democratic } \\
\text { state. Top-down diffusion, } \\
\text { some public participation. }\end{array}$ & $\begin{array}{l}\text { Centralised, democratic } \\
\text { state. Top-down diffusion, } \\
\text { some public participation. }\end{array}$ & $\begin{array}{l}\text { Strongly centralised, mostly top- } \\
\text { down diffusion of policy with } \\
\text { limited public participation. }\end{array}$ \\
\hline Past and present policies & $\begin{array}{l}\text { Core aims are to expand transport } \\
\text { supply within strict budget } \\
\text { constraints. Land use tightly } \\
\text { controlled. } 75 \% \text { of land is state- } \\
\text { owned. Policy is to limit urban } \\
\text { growth to maintain densities. }\end{array}$ & $\begin{array}{l}\text { Dominant political aim to } \\
\text { maximise economic growth. } \\
\text { Land use controls and } \\
\text { transport policies relatively } \\
\text { weak. }\end{array}$ & $\begin{array}{l}\text { Weak land use controls and } \\
\text { transport policies. }\end{array}$ & $\begin{array}{l}\text { Highly planned, } 50 \text { year land use } \\
\text { plan. Core aims to develop as the } \\
\text { main hub for the financial and } \\
\text { high-tech sectors for Southeast } \\
\text { Asia. }\end{array}$ \\
\hline Institutions and bureaucracy & $\begin{array}{l}\text { Command and control - strongly } \\
\text { regulated by Central Government. } \\
\text { Transport system publicly owned, } \\
\text { hierarchical and well planned. }\end{array}$ & $\begin{array}{l}\text { Based on UK Parliamentary } \\
\text { system. Largely privatised } \\
\text { bus system. }\end{array}$ & $\begin{array}{l}\text { Based on UK Parliamentary } \\
\text { system. Predominantly } \\
\text { private buses with high } \\
\text { government subsidies. }\end{array}$ & $\begin{array}{l}\text { Strong control from government } \\
\text { regulations. Bus and rail } \\
\text { predominantly publicly owned. }\end{array}$ \\
\hline $\begin{array}{l}\text { Economic (GDP) growth }(\%), \\
\text { 2005, estimate }\end{array}$ & 8.0 & 2.5 & 1.0 & 6.4 \\
\hline $\begin{array}{l}\text { Bertram \& Poirine }(2007) \\
\text { Classification }- \text { total share of } \\
\text { imports of goods and services } \\
\text { by sector }(\% \text { GDP) }\end{array}$ & $\begin{array}{l}\text { Diversified economy: export plus } \\
\text { tourism }(33 \% \text { plus } 33 \%) \text {. }\end{array}$ & Export led $(60.0 \%)$ & $\begin{array}{l}\text { Export led with some high } \\
\text { value exports }(77.3 \%) \text {. }\end{array}$ & $\begin{array}{l}\text { Export led with many high value } \\
\text { exports }(92.3 \%) \text {. }\end{array}$ \\
\hline Economic conditions & $\begin{array}{l}\text { Gradual shift towards more market } \\
\text { based economy, longer term } \\
\text { somewhat unclear. }\end{array}$ & $\begin{array}{l}\text { Slow shift from socialist to } \\
\text { free market economy. Shift } \\
\text { from reliance on sugar to } \\
\text { textiles, tourism, high tech } \\
\text { and finance. }\end{array}$ & $\begin{array}{l}\text { More growth due to } \\
\text { connectivity in EU- } \\
\text { membership. }\end{array}$ & $\begin{array}{l}\text { Brief downturn in } 2003 \text { (SARS) } \\
\text { affected tourism and consumer } \\
\text { spending. }\end{array}$ \\
\hline
\end{tabular}




\begin{tabular}{|c|c|c|c|c|}
\hline $\begin{array}{l}\text { Human Development Index } \\
\text { (2002). Incorporates life } \\
\text { expectancy, educational } \\
\text { attainment and decent } \\
\text { standard of living. Ranges } \\
\text { from 0.956 (Norway) to } \\
0.273 \text { (Sierra Leone) (UNDP, } \\
2004) \text {. }\end{array}$ & $\begin{array}{l}0.809 . \\
\text { Life expectancy index }-\end{array}$ & $\begin{array}{l}0.785 \\
\text { Life expectancy index }- \\
0.78 \\
\text { Education index }-0.79 \\
\text { GDP index }- \\
\text { Ranked 64/177. }\end{array}$ & $\begin{array}{l}0.875 \\
\text { Life expectancy index }- \\
0.89 \text { Education index }-0.87 \\
\text { GDP index }- \\
\text { Ranked 31/177. }\end{array}$ & 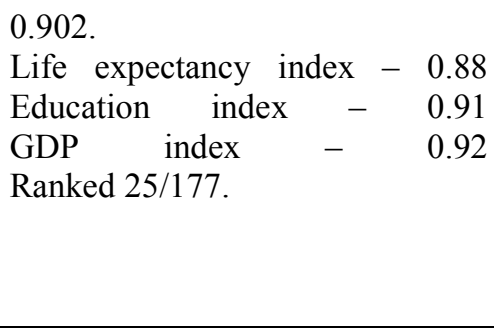 \\
\hline $\begin{array}{l}\text { Happy Planet Index }(2003-5) \\
\text { (Marks et al., 2006). } \\
\text { Reasonable Ideal Value is } \\
83.5 \text { but highest value } 68.2 \\
\text { for Vanuatu. Lowest } 16.6 \text { for } \\
\text { Zimbabwe }\end{array}$ & $\begin{array}{l}61.9 \text { (good life expectancy, medium } \\
\text { personal satisfaction and low } \\
\text { ecological footprint). Ranked } 6 / 178\end{array}$ & $\begin{array}{l}49.6 \quad \text { average } \text { life } \\
\text { expectancy, medium } \\
\text { personal satisfaction and } \\
\text { medium a ecological } \\
\text { footprint). }\end{array}$ & $\begin{array}{l}53.3 \text { (good life expectancy, } \\
\text { very high personal } \\
\text { satisfaction and high } \\
\text { ecological } \\
\text { Ranked } 40 / 178\end{array}$ & $\begin{array}{l}36.1 \text { (good life expectancy, high } \\
\text { personal satisfaction and very } \\
\text { high ecological footprint). } \\
\text { Ranked } 131 / 178\end{array}$ \\
\hline $\begin{array}{l}\text { Drivers and examples of } \\
\text { technical innovation }\end{array}$ & $\begin{array}{l}\text { High level of appropriate transport } \\
\text { technologies e.g. camello bus } \\
\text { network, animal traction, cycle bus } \\
\text { system, organised car sharing as well } \\
\text { as policy innovations e.g. reducing } \\
\text { commuting distances through } \\
\text { job/home relocations, petrol rationing } \\
\text { etc. }\end{array}$ & $\begin{array}{l}\text { A rapidly growing economy } \\
\text { leading to a lack of capacity } \\
\text { probably requiring new } \\
\text { modes like use of taxi-train, } \\
\text { and networks to supplement } \\
\text { the bus systems. Potential } \\
\text { for a future guided busway } \\
\text { system. }\end{array}$ & $\begin{array}{l}\text { Limited drivers for } \\
\text { innovation. Redeveloped } \\
\text { bus network and re- } \\
\text { appraisal of tourism impacts } \\
\text { on bus patronage. Use of } \\
\text { number plate recognition } \\
\text { technology in road user } \\
\text { charging scheme. }\end{array}$ & $\begin{array}{l}\text { Desire to maintain steady, } \\
\text { predictable, efficient traffic flow } \\
\text { led to a full range of economic } \\
\text { and regulatory instruments to } \\
\text { maintain access. High technology } \\
\text { measures well embedded into } \\
\text { society. }\end{array}$ \\
\hline
\end{tabular}


Table 6: Land and transport-related descriptor factors (based on Attard, 2005, Enoch \& Warren, 2008)

\begin{tabular}{|c|c|c|c|c|}
\hline Parameter & Cuba & Mauritius & Malta & Singapore \\
\hline Settlement form & $\begin{array}{l}\text { Capital city of } 2.2 \mathrm{~m} \text {, and } 13 \\
\text { cities of more than } 100,000 \text {. } \\
\text { Urbanised population of } \\
75 \% \text {. Very limited sprawl. }\end{array}$ & $\begin{array}{l}\text { Approx } 45 \% \text { living in capital } \\
\text { and four other major } \\
\text { settlements close by. }\end{array}$ & $\begin{array}{l}\text { Lack of land. High density with } \\
\text { population centres around the } \\
\text { capital and port. Urbanization is } \\
\sim 90 \% \text {. }\end{array}$ & $\begin{array}{l}\text { Highly planned with central core area } \\
(730,000 \text { living in centre) } \sim 100 \% \text { urbanised } \\
\text { city-state. }\end{array}$ \\
\hline Activity Patterns & $\begin{array}{l}\text { High percentage of socially } \\
\text { necessary trips. Demand } \\
\begin{array}{l}\text { constrained by supply } \\
\text { shortages. }\end{array}\end{array}$ & $\begin{array}{l}\text { Growing bus and car use } \\
\text { serving increasing female } \\
\text { workforce. Increased dispersal } \\
\text { of activities. }\end{array}$ & $\begin{array}{l}\text { High car ownership tending } \\
\text { towards saturation, with strong } \\
\text { social acceptance of car use as } \\
\text { basic need. }\end{array}$ & $\begin{array}{l}\text { High levels of public transport use (bus } \\
32 \% \text {, metro } 15 \%) \text {, car sharing }(42 \%) \text { and } \\
\text { taxi }(11 \%) \text { due to long term land use plan } \\
\text { and high investment. }\end{array}$ \\
\hline Transport infrastructure & $\begin{array}{l}\text { Road network: } 60858 \mathrm{~km} \text {; } \\
\text { Rail network: } 11151 \mathrm{~km} \text {. } \\
\text { Generally roads in poor } \\
\text { state of repair. }\end{array}$ & $\begin{array}{l}2000 \mathrm{~km} \text { road in good } \\
\text { condition. }\end{array}$ & $\begin{array}{l}2227 \mathrm{~km} \text { roads; roads generally } \\
\text { good with a radial network } \\
\text { extending from capital to all } \\
\text { parts of the island. }\end{array}$ & $\begin{array}{l}3130 \mathrm{~km} \text { roads in good or very good } \\
\text { condition with high investment in public } \\
\text { transport systems. }\end{array}$ \\
\hline Public transport ridership & $\begin{array}{l}\text { Havana: } 17 \% \text { motorized } \\
\text { public transport; }(57 \% \text { of } \\
\text { trips are non motorized }) .\end{array}$ & $\begin{array}{l}\text { Relies on a mixture of bus and } \\
\text { shared taxi modes to meet } \\
\text { demand. }\end{array}$ & $\begin{array}{l}\text { Relies on extensive bus network } \\
(\sim 30 \% \text { of all trips), connecting } \\
\text { mainly to the capital Valletta. }\end{array}$ & $\begin{array}{l}\text { Integrated bus/metro system. Bus links new } \\
\text { town residential areas to central business } \\
\text { district. Development focused on metro. }\end{array}$ \\
\hline Quality of service & $\begin{array}{l}\text { Service quality very low due } \\
\text { to shortage of capacity and } \\
\text { high level of demand. }\end{array}$ & $\begin{array}{l}\text { Service quality is limited, both } \\
\text { at peak (overcrowding) and } \\
\text { off-peak (lack of services). }\end{array}$ & $\begin{array}{l}\text { Good connectivity (most people } \\
\text { within } 15 \text { minutes of a stop). }\end{array}$ & $\begin{array}{l}\text { Very good public transport systems and } \\
\text { high tech based personal car use systems. }\end{array}$ \\
\hline $\begin{array}{l}\text { Direct user charges (e.g. } \\
\text { tolls) }\end{array}$ & $\begin{array}{l}\text { Road tolls on two tourist } \\
\text { routes; } \$ 2-5 \text { per crossing. }\end{array}$ & $\begin{array}{l}\text { Some parking charges in } \\
\text { major urban areas. }\end{array}$ & $\begin{array}{l}\text { Capital city entrance tax } \sim \text { US } \\
\$ 60 / y r \text {, limited parking charges. }\end{array}$ & $\begin{array}{l}\text { ERP (electronic road pricing) in central } \\
\text { urban area and some highways plus parking } \\
\text { charges and restrictions. }\end{array}$ \\
\hline $\begin{array}{l}\text { Fuel cost (\$/litre), diesel; } \\
\text { petrol }\end{array}$ & $0.45 ; 0.90$ & $0.56 ; 0.74$ & $0.53 ; 0.87$ & $0.38 ; 0.85$ \\
\hline $\begin{array}{l}\text { Vehicle cost (purchase } \\
\text { price) }\end{array}$ & $\begin{array}{l}\text { Very high: lack of personal } \\
\text { income. }\end{array}$ & $\begin{array}{l}\text { High: due to isolation of } \\
\text { market. }\end{array}$ & $\begin{array}{l}\text { Fairly high: due to isolation of } \\
\text { market. }\end{array}$ & Very high: due to high taxation. \\
\hline GDP (\$/capita, PPP) & $\$ 2545(2003)$ & 3779 & 9245 & 20544 \\
\hline $\begin{array}{ll}\begin{array}{l}\text { Vehicle } \\
\text { (veh./1000) }\end{array} & \text { ownership } \\
\end{array}$ & $\sim 45$ & $\sim 111$ & $\sim 675$ & $\sim 175$ \\
\hline
\end{tabular}


Figure 3 depicts the increasing level of car ownership (y-axis, vehicles per 1,000 inhabitants in a country) as a function of both time and income (x-axis). The time series shown here is typically 1977-2009, except for the United States (plotted here to indicate the trajectory of the world's most automobile-centric nation). This is a longer data series which is represented by unfilled squares (1950-1976) and filled squares (1977-2004).

The growth in car ownership has direct implications for car use, congestion, fuel use and emissions and so much depends on exactly what the maximum level will eventually be for each country. At this point it is interesting to observe that car ownership levels in the United States appear to have stabilized at roughly 800 vehicles per 1,000 population whereas the figure for Singapore is around 100. So far it is unclear at which level car ownership will stabilize at for Cuba and Mauritius, although growth in Malta does now appear to be slowing. In other words, island states like Cuba and Mauritius need to decide on their future development trajectories with respect to wealth and personal car ownership and therefore use. Should they follow the high wealth/high car ownership/use 'Maltese' model, or the high wealth/low car ownership/use model adopted by the Singaporeans?

Figure 3: Motorization rates as function of income. Sources: USA adapted from Davis et al.; Cuba from ONE; Malta, Singapore and Mauritius adapted from Euromonitor International (GMID database). Income values from Heston et al. (2009).

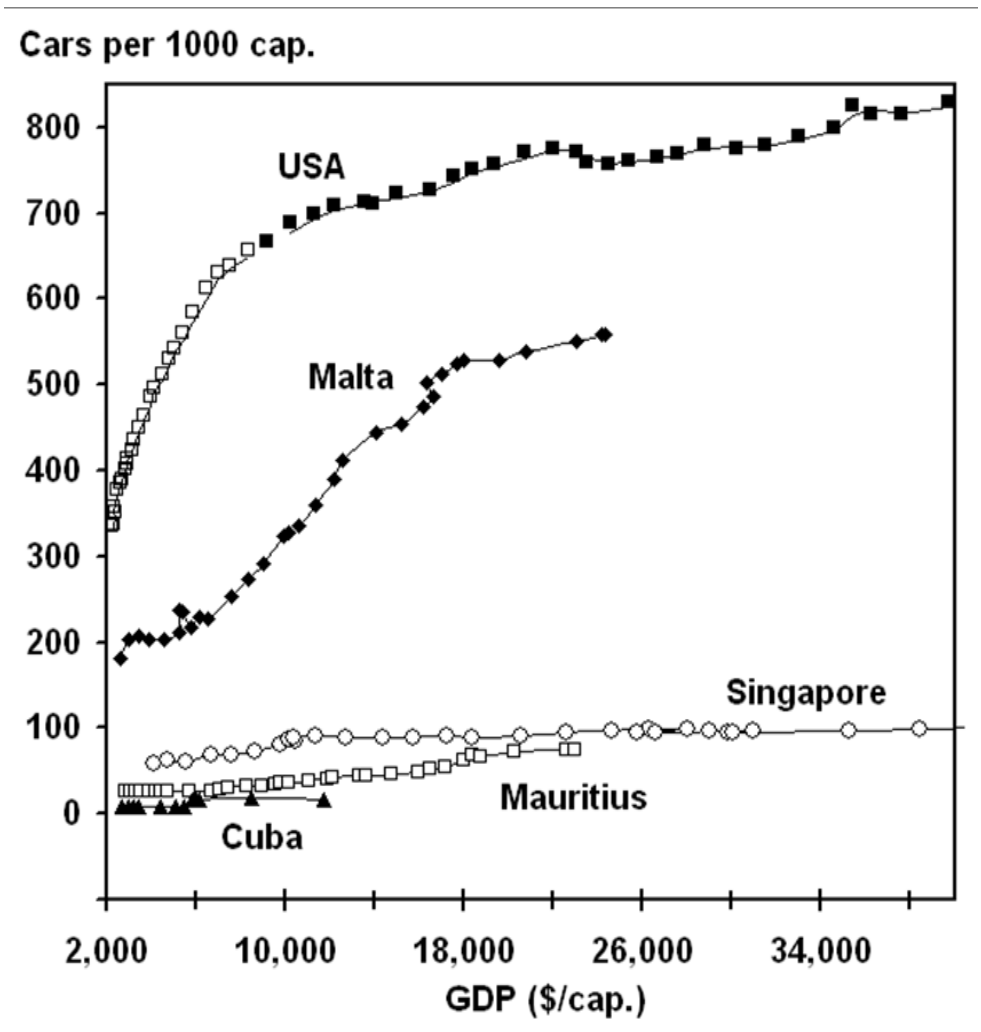




\section{J. Warren \& M. Enoch}

\section{Conclusions}

This paper has sought to consider how various contextual factors have influenced the development of transport systems in the four island cases. To do so, some of the shaping factors encountered in Cuba, Mauritius, Malta and Singapore have been explored, and how the transport systems have developed in these situations has been investigated. Moreover, some indications as to the extent to which these issues may be island-related have been presented.

In summarizing the four cases, swingeing economic shortages in Cuba coupled with strong political leadership led to a series of innovative technological and policy responses to the resulting shortage of transport capacity, several of which (e.g. compulsory lift sharing schemes and reducing journey distances by home and/or job swaps) have not emerged anywhere else. Cuba's motorization levels are very low and probably will only grow if there are major changes within the economic framework of the country. Interestingly, historic levels of ownership were much higher, and comparable to the United States, but are currently stagnated.

In Mauritius, the rapid growth in the economy caused by several factors (e.g. the increasing population, increasing incomes, migration from rural to urban areas and the greater participation of women in the workforce) has overstretched the existing bus system. This necessitated an increase in public transport capacity through implementing the taxitrain shared taxi scheme but also contributed to increased car ownership. On top of this, elected Governments seem unable to address the high demand for cars by the (very real) political risk of losing power should they introduce any kind of 'anti-car' measure. Mauritius has had a large increase in ownership of cars and is set to surpass motorization levels of Singapore in the short term future if growth continues at the current rate. It is not yet clear how high these levels will rise without further analysis.

Similarly, Malta has experienced increased personal wealth and a corresponding rise in the demand for travel which the bus system was apparently unable to meet. And again, as in Mauritius political power rests on "an edge" such that one unpopular decision (such as restricting car use) would seriously damage the ruling party's chances of regaining power during a subsequent election. In addition, there is a strong cultural effect whereby car ownership is equated with being a success and bus use is socially looked down upon which appears to have played an exaggerated role in driving up car borne mobility still further. Malta clearly seems to have a motorization rate which is assimilating towards the United States-like saturation point with high car ownership.

Meanwhile Singapore represents a case where strong Government policies have steered development in a planned and controlled way such that the car forms just one viable transport option among several. This is despite the fastest and highest level of economic growth of the four vignettes considered; yet this country also has environmental impacts associated with high economic growth coupled with higher consumption.

Finally, in determining the influence of 'islandness' on the transport systems of the four vignettes, it is helpful to revisit the categories identified in Enoch \& Warren (2008), namely: smallness, remoteness, demographics and economics. 


\section{Smallness}

- Islands generally see facilities located close to one another.

Clearly Cuba is not small in population or area, while Singapore has a fairly large population in a small space. However, all four islands are densely populated with high levels of urbanization - particularly in Mauritius and Malta. The transport system networks in all four cases are also strongly focused on the capital cities.

- Political structures are fairly flat vis-à-vis larger countries, therefore making decision making chains rather more direct.

This is particularly true in Mauritius and Malta, where relatively small constituencies mean that politicians are extremely aware of the needs/wishes of the voters. Centralised decision making processes in Cuba and Singapore are possibly less due to 'islandness' than to unitary and centralized political and institutional systems.

- One would suspect that while the first factor would negate the need or demand for travel to some extent, the second may well increase pressure on decision makers to enhance rather than restrict car use.

Radical decisions have been taken in Cuba and Singapore to limit car use due to unique political circumstances in each case. However, significant political pressure in Mauritius and Malta has tended to force Governments there to adopt supply side ahead of demand side measures to address transport problems, a tendency which is only now being overcome.

\section{Remoteness}

- Increased levels of remoteness mean high external transport costs limiting the supply of 'transport'.

This was true in Cuba (where the Economic Blockade has significantly increased external transport costs), and anecdotally reported in Mauritius. It was seemingly not an issue in Malta or Singapore.

- It could also mean that the competitive threat from neighbouring jurisdictions is reduced.

Competitive threats from neighbouring jurisdictions were not identified as being a major issue, even internally, in any of the four cases. This is probably because the most radical policy measures were proposed either at the national level or only for the major urban centres where transport users would not have much choice about their destination.

- The implication here would be that introducing potentially unpopular policies to restrict traffic growth may be more politically feasible than elsewhere.

However, it should also be noted that pressure in the opposite direction (i.e. preventing 'anti-car' policies) may also be higher due to the 'flatter' and more localised decision making institutional framework whereby politicians are more directly influenced by the local electorates - this certainly seems to be the case in both Mauritius and Malta. 


\section{J. Warren \& M. Enoch}

\section{Demographics}

- Island populations tend to be concentrated in a limited number of centres.

All four islands are densely populated with high levels of urbanization - particularly in Mauritius and Malta. The transport system networks in all four cases are also heavily focused on the capital cities.

- Island populations tend to be strongly influenced by rapid population changes.

Demand for transport has rapidly increased in Mauritius due to factors such as population growth and the increased participation of women in the workforce. Population changes in the other three cases though have been relatively limited, likely due to the unique economic circumstances in low income Cuba, and the relatively high levels of GDP per capita in Malta and Singapore.

- Together, these trends are likely to exacerbate pressure on land in key locations and thus multiply the externalities caused by the transport system more quickly and more severely than elsewhere.

In Cuba a severe lack of (public) transport capacity since that early 1990s is now thought to be easing slightly although there remains a significant level of suppressed demand. Meanwhile traffic conditions in Mauritius and Malta have worsened significantly in recent years and have led to some relatively small scale, transport demand management-inspired policy interventions in both cases. By contrast, long term land use and transport planning processes have been more successful in managing these issues in Singapore ever since the mid 1970s.

\section{Economics}

- Diseconomies of scale make it relatively more expensive to provide transport services and to import vehicles, spare parts, fuel and materials for infrastructure development.

There is anecdotal evidence of this problem in Mauritius, but no such evidence was reported regarding Singapore and Malta (which are islands that are rather less isolated from neighbouring countries than Mauritius in particular). Meanwhile, the case of Cuba needs to be mentioned here as it is possibly the extreme case worldwide of this phenomenon. However, this is almost entirely due to the Economic Blockade imposed by the United States since the early 1960s.

- Islands are particularly vulnerable to fluctuations in energy prices.

No direct evidence of this was determined.

- These pressures would seem to lead Island Governments to consider managing car use through restricting travel demand and or improving alternatives rather earlier than elsewhere.

The cases chosen seem to indicate that this is so. However, these island states are far from typical; indeed, one of the selection criteria was that the cases be 'interesting' contextually and from a policy standpoint. 
Overall, the findings illustrate that economic, social, technological and political factors strongly influence whether transport systems evolve in a way where car use is (or is becoming) dominant - as in Malta and Mauritius - or whether it is less so - as in Cuba and Singapore. The role of the automobile within the transport systems for islands, and its key modal dominance in providing the majority of the overall personal car use, needs further exploration and examination to fully map all of the issues of sustainability.

\section{Acknowledgements}

This paper has benefited from feedback during the 'Islands of the World IX' Conference and from helpful suggestions from the reviewers and the Editor. Thanks to D.N.P. Mootien for data collection (Mauritius), to M. Attard (Malta vignette), and to G.F. Smith (vehicle data). The usual disclaimers apply.

\section{References}

Attard, M. (2005) 'Land Transport Policy in a Small Island State: The Case of Malta', Transport Policy, Vol. 12, No. 1, pp. 23-33.

Attard, M. \& Hall, D. (2003) 'Public Transport Modernization and Adjustment to EU Accession Requirements: The Case of Malta's Buses', Journal of Transport Geography, Vol. 11, No. 1, pp. 13-24.

Attard, M. \& Ison, S. (2010) 'Implementation of Road User Charging and Lessons Learnt: The Case of Valletta, Malta', Journal of Transport Geography, Vol. 18, No. 1, pp. 14-22.

Bertram, G. \& Poirine, B. (2007) 'Island Political Economy' in G. Baldacchino (ed.) A World of Islands: An Island Studies Reader, Charlottetown, Canada and Luqa, Malta, Institute of Island Studies and Agenda Academic, pp. 325-377.

Bramwell, B. (2006) 'Actors, Power, and Discourses of Growth Limits', Annals of Tourism Research, Vol. 33, No. 4, pp. 957-978.

Briguglio, L. (2004) 'Economic Vulnerability and Resilience: Concepts and Measurements' in L. Briguglio \& E.J. Kisanga (eds.) Economic Vulnerability and Resilience of Small States, Malta, Formatek, pp. 43-53.

Button, K., Ngoe, N. \& Hine, J. (1993) 'Modelling Vehicle Ownership and Use in Low Income Countries', Journal of Transport Economics \& Policy, Vol. 27, No. 1, pp. 51-67.

Central Intelligence Agency (2006) The World Factbook 2005, Washington DC, CIA, www.cia.gov/library/publications/the-world-factbook/index.html. 


\section{J. Warren \& M. Enoch}

Dargay, J. \& Gately, D. (1999) 'Income's Effect on Car and Vehicle Ownership, Worldwide: 1960-2015', Transportation Research A, Vol. 33, No. 2, pp. 101-138.

Davis, S.C., Diegel, S.W. \& Boundy, R.G. (2009) Transportation Energy Data Book, $28^{\text {th }}$ Edition (reference no ORNL-6984), Oak Ridge National Laboratory, Oak Ridge, Tennessee 37831-6073.

Durbarry, R. (2004) 'Tourism and Economic Growth: The Case of Mauritius', Tourism Economics, Vol. 10, No. 4, pp. 389-401.

Enoch, M.P. (2003) 'Transport Practice and Policy in Mauritius', Journal of Transport Geography, Vol. 11, No. 4, pp. 297-306.

Enoch, M.P., Warren, J.P., Rios, H.V. \& Menoyo, E.H. (2004) 'The Effect of Economic Restrictions on Transport Practices in Cuba', Transport Policy, Vol. 11, No .1, pp. 67-76.

Enoch, M.P. \& Warren, J.P. (2008) 'Automobile Use within Selected Island States', Transportation Research A, Vol. 42, No. 9, pp.1208-1219.

Euromonitor International (2010) GMID and Euromonitor Database, www.portal.euromonitor.com.libezproxy.open.ac.uk/Portal/Statistics.aspx/ See 'Passenger Cars in Use Category', with data from European Automobile Manufacturers' Association (ACEA) \& International Road Federation (IRF).

European Commission (2006) EU Energy and Transport in Figures, Statistical Pocketbook 2005, Brussels, European Commission.

Gakenheimer, R. (1999) 'Urban Mobility in the Developing World', Transportation Research A, Vol. 33, Nos. 7-8, pp. 671-689.

Global Footprint Network (2006) Asia Pacific Global Footprint Accounts 2005. www.footprintnetwork.org/download.php?id=9.

Halcrow Fox \& MDS Transmodal (2001) Integrated National Transport Strategy Study, Summary Report (Final), Republic of Mauritius, April, www.gov.mu/portal/goc/mpi/file/summary.pdf.

Heston, A., Summers, R. \& Aten, B. (2009) Penn World Tables, Version 6.3, Center for International Comparisons of Production, Income and Prices at University of Pennsylvania, August, http://pwt.econ.upenn.edu/php_site/pwt index.php.

International Road Federation (2005) World Road Statistics 2005, Geneva, International Road Federation. 
Jatar-Hausman, A.J. (1999) The Cuban Way: Capitalism, Communism and Confrontation, Bloomfield CT, Kumarian Press.

Kakazu, H. (1994) Sustainable Development of Small Island Economies, Oxford, Westview Press.

Kekic, L. (2006) Index of Democracy: The World in 2007, The Economist Intelligence Unit, pp.1-11, www.economist.com/media/pdf/Democracy_Index_2007_v3.pdf.

Kian-Keong, C. \& Menon, A.P.G. (2004) 'ERP in Singapore: What has been learnt from Five Years of Operation?', Traffic Engineering \& Control, Vol. 45, No. 2.

Lockhart, D.G., Drakakis-Smith, D. \& Schembri, J.A. (1993) The Development Process in Small Island States, London, Routledge.

Marks, N., Abdallah, S., Simms, A. \& Thompson, S. (2006) The Happy Planet Index, First Report, London, New Economics Foundation, www.happyplanetindex.org/publicdata/files/happy-planet-index-first-global.pdf.

Menon, G. (2004) Report on Congestion Pricing in Port Louis, Ministry of Public Infrastructure \& Land Transport, Republic of Mauritius, June, www.gov.mu/portal/goc/mpi/file/congest.doc.

NSO Malta (2006) Transport Statistics 2006, 14 July, Malta, National Statistics Office, www.nso.gov.mt/statdoc/document file.aspx?id=2282.

Nurse, L.A. \& Sem, G. (2001) 'Small Island States' in J.J. McCarthy, O.F. Canziani, N.A. Leary, D.J. Dokken \& K.S. White (eds.) Climate Change 2001: Impacts, Adaption and Vulnerability, Cambridge, Cambridge University Press, pp. 843-877.

ONE (1980-2006) Annuario Estadístico de Cuba, Oficina Nacional de Estadísticas, Havana, Cuba. Editions for 1980, 1981, 1982, 1988, 1989, 2001, 2002, and 2006.

Pelling, M. \& Uitto, J.I. (2001) 'Small Island Developing States: Natural Disaster Vulnerability and Global Change’, Environmental Hazards, Vol. 3, No. 2, pp. 49-62.

Potter, S. \& Warren, J.P. (2007) 'Conclusion: From Here to Eco-ternity', in J.P. Warren (ed.) Managing Transport Energy, Oxford, Oxford University Press, pp. 153-167.

Richmond, J.E.D. (2006) Mauritius Transport Consensus Forums: Briefing to Honourable Members of the Cabinet, Government of Mauritius, Port Louis, 28 September, pp. 1-26. 
Richmond, J.E.D. (2008) 'Transporting Singapore: The Air-Conditioned Nation', Transport Reviews, Vol. 28, No. 3, pp. 357-390.

Tanner, J.C. (1983) 'International Comparison of Cars and Car Usage', TRRL Report 1070, Crowthorne, Berkshire, UK, Access and Mobility Division, Transport Operations Department, Transport Road Research Laboratory.

United Nations Development Program (2004) 'Cultural Liberty in Today's Diverse World' in Human Development Report 2004: New York, UNDP, pp. 139-146, http://hdr.undp.org/en/media/hdr04_HDI1.pdf.

Weisser, D. (2004) 'On the Economics of Electricity Consumption in Small Island Developing States: A Role for Renewable Energy Technologies?', Energy Policy, Vol. 32, No. 1, pp. 127-140.

Willoughby, C. (2001) 'Singapore's Motorization Policies: 1960-2000', Transport Policy, Vol. 8, No. 2, pp. 125-139. 